\title{
The Metaphysics of Crackle:
}

\author{
Afrofuturism AND HAUntology \\ $\bullet$ Feature Article $\longrightarrow$ \\ MARK FISHER \\ Goldsmiths, University of London / University of East London (UK)
}

\begin{abstract}
There has always been an intrinsically "hauntological" dimension to recorded music. But Derrida's concept of hauntology has gained a new currency in the $21^{\text {st }}$ century, when music has lost its sense of futurism, and succumbed to the pastiche- and retrotime of postmodernity. The emergence of a $21^{\text {st }}$ century sonic hauntology is a sign that "white" culture can no longer escape the temporal disjunctions that have been constitutive of the Afrodiasporic experience since Africans were first abducted by slavers and projected from their own lifeworld into the abstract space-time of Capital. Time was always-already out of joint for the slave, and Afrofuturism and hauntology can now be heard as two versions of the same condition.
\end{abstract}

KEYWORDS: Hauntology, Afrofuturism, dub, phonography, rockism

MARK Fisher is the author of Capitalist Realism (2009) and the forthcoming Ghosts Of My Life: Writings on Depression, Hauntology and Lost Futures. His writing has appeared in many publications, including The Wire, Frieze, The Guardian and Film Quarterly. He is Programme Leader of the MA in Aural and Visual Cultures at Goldsmiths, University of London and a lecturer at the University of East London.

Dancecult: Journal of Electronic Dance Music Culture 5(2): 42-55 ISSN 1947-5403 @2013 Dancecult http://dj.dancecult.net DOI 10.12801/1947-5403.2013.05.02.03 
[In] "Phonograph Blues" ... Johnson sings, with too much emotion it seems, about his broken record player. "What evil have I done ... what evil has the poor girl heard". That one line tells you how far he is trying to go.

The poor girl is the phonograph, softly personified; she refuses to play Johnson's wicked records and breaks down.

-Greil Marcus (1977: 26)

For Techno, Dusseldorf is the Mississippi Delta.

-Kodwo Eshun (1998: 07[100])

The way that Tricky works - fucking around with sounds on the sampler until his sources are unrecognisable wraiths, ghosts of their former selves; composing music and words spontaneously in the studio; mixing tracks live as they're recorded; retaining the glitches and inspired errors, the hiss and crackle —all this is strikingly akin to early Seventies dubmeisters like King Tubby.

-Simon Reynolds (1995)

Dub messes big time with ... notions of uncorrupted temporality. Wearing a dubble face, neither future nor past, Dub is simultaneously a past and future trace: of music as both memory or futurity, authentic emotion and technological parasitism.

-Ian Penman (1995)

IN HIS LANDMARK 1995 PIECE ON TRICKY, “[the Phantoms of] TRICKNOLOGY [versus a Politics of Authenticity]", Ian Penman expressed some misgivings about the work of rock journalist Greil Marcus. "Much as I love his writing", Penman wrote, "the objects of his adoration often baffle me, especially when it comes to his attempted negotiation of 'politics' in music, specifically a certain strain of worthy, invariably English avatar (Mekons, Gang of Four, Strummer, Costello; also Bruce Springsteen): a certain strain of SPOKESPERSON that some of us have never been swayed by, distrusted as being way literal in its approach, texturally meagre". What Marcus' work, for all its merits, consistently fails to encounter is production. References to producers - or production techniques-in Marcus are, at best, fleeting.

Is Marcus's writing - with its privileging of voice, live performance, spontaneity-rock writing's version of what Derrida calls the "metaphysics of presence" (see Derrida 1976)? For Derrida, the metaphysics of presence rested in part on the notion that meaning could be secured and settled via an anchoring to a body. Writing, by contrast, was construed as something inauthentic, deferred, absent. What concerns us here is not, though, the opposition between the voice and writing, but the (equally deconstructible) opposition between two ways of hearing (or treating) the voice: the voice as (authorised and authentic) 
embodied presence versus the voice as recorded revenant. ${ }^{1}$ What is repressed here is not writing, but phonography.

It is perhaps in the idea of a rock "metaphysics of presence" that we are getting to what is fundamentally at stake in the deeply contested term "rockism". Rockist criticism always prefers the authentic to the synthetic, the live to the recorded. Without using the term, Kodwo Eshun identified the principal characteristics of rockism in a broadside at the beginning of his More Brilliant Than The Sun (1998), railing against a default emphasis, in certain critical quarters, on "the live show, the proper album, the Real Song, the Real Voice, the mature, the musical, the pure, the true, the proper, the intelligent" (1998: 01[006]). What is repressed in the emphasis on liveness and authenticity is the very condition of our access to these performances: the technology of recording, something which comes to the fore in dub (which is why Penman treats dub - the Afrofuturist sonic science par excellence-as the anti-type of Marcus' "measured humanism which leaves little room for the UNCANNY in music"). "Dub", Penman wrote, "was a breakthrough because the seam of its recording was turned inside out for us to hear and exult in; when we had been used to the 're' of recording being repressed, recessed, as though it really were just a re-presentation of something that already existed in its own right" (1995). Now this isn't to say that Marcus doesn't like or write about dub. Dub, in fact, is exactly the sort of thing Marcus will refer to in reverential terms, but his encounter with it is only ever glancing. Ironically, it may be Marcus' debt to literary criticism - to a theory based in texts - which impedes Marcus from focusing on texture: on the grainy materiality of sound, sound as a medium in itself rather than as a carrier for Meaning. The point here is not to upbraid Marcus, but rather to treat his writing as symptomatic of a certain tendency in rock writing to avoid engagement with texture... and spectrality.

Texture is central to both Afrofuturism and what I and others have been calling "sonic hauntology". The concept of hauntology was derived-it would probably be better to say sampled-from Derrida's Specters Of Marx (originally published in English in 1994; 2006). In Derrida's work, "hauntology" was a play on "ontology". The concept of hauntology was in part a restatement of the key deconstructive claim that "being" is not equivalent to presence. Since there is no point of pure origin, only the time of the "always-already", then haunting is the state proper to being as such. As Peter Buse and Andrew Stott explain:

Ghosts arrive from the past and appear in the present. However, the ghost cannot be properly said to belong to the past. . . . Does then the 'historical' person who is identified with the ghost properly belong to the present? Surely not, as the idea of a return from death fractures all traditional conceptions of temporality. The temporality to which the ghost is subject is therefore paradoxical, at once they 'return' and make their apparitional debut. Derrida has been pleased to call this dual movement of return and inauguration a 'hauntology', a coinage that suggests a spectrally deferred non-origin within grounding metaphysical terms such as history and identity. This idea will be familiar from other Derridean discussions of event and causality in essays 
such as "Before The Law", and "Signature Event Context"... Such an idea also informs the well-known discussion of the origin of language in Of Grammatology, where ... any attempt to isolate the origin of language will find its inaugural moment already dependent upon a system of linguistic differences that have been installed prior to the 'originary' moment (Buse and Scott 1999: 11).

Around 2006, writers such as Simon Reynolds and myself turned to the concept of hauntology when spectrality started to emerge as a theme-and a practice-in the work of producers from a range of backgrounds, including experimental rocker Ariel Pink, composer William Basinski, turntablist Philip Jeck, and the dubstepper Burial. "Hauntology" also suggested itself as the most fitting classificatory label for some producers who did not obviously belong to an existing genre, such as The Caretaker and the artists on the Ghost Box label. The work of The Caretaker was bound up with spectrality from the very beginning: the name "The Caretaker" was a reference to the role that the Jack Nicholson character ends up - or perhaps was always-already_playing in Stanley Kubrick's The Shining (1980), and The Caretaker's slowed down and reverbed samplings of English pop from the 1930s and 40 s were originally conceived of as the kind of music that could be played in Kubrick's Overlook Hotel. The Ghost Box label, meanwhile, is based on a kind of "re-dreaming" of British media culture between 1958 and 1978. Its music and covert art constitute an oneiric conflation of weird fiction, the music of the BBC Radiophonic Workshop and the lost public spaces of the so-called postwar consensus (a consensus that was terminated with the election of Margaret Thatcher in 1979). Sonic hauntology is exercised by the problem of memory and its imperfect recovery; a familiar enough theme, but one given an extra piquancy in the context of electronic music, which was for so long treated as a herald and signifier of the future. Here we confront the temporal crisis around which sonic hauntology is continually circling. The problem is that the electronic sounds produced between the 1950 s and the 1990s remain sonic signifiers of the future-and, as such, they are signs that the anticipated future never actually arrived. The music of Burial and of Ghost Box is haunted by a paradoxical nostalgia: a nostalgia for all the futures that were lost when culture's modernist impetus succumbed to the terminal temporality of postmodernity. There is a certain irony here, because, if Fredric Jameson is to believed, then postmodernism is itself dominated by "the nostalgia mode". It is important to be clear about what Jameson means by the "nostalgia mode" (1991). He does not mean psychological nostalgia-indeed, the nostalgia mode as Jameson theorises it might preclude psychological nostalgia, since it arises only when a coherent sense of historical time breaks down. Postmodernism's nostalgia mode is not defined by a yearning for the past. The kind of figure capable of exhibiting and expressing such longing belongs to a paradigmatically modernist moment-think, for instance, of Proust's and Joyce's ingenious exercises in recovering lost time. Jameson's nostalgia mode is better understood in terms of a formal attachment to the techniques and formulas of the past, a consequence of a retreat from the modernist challenge of innovating cultural forms adequate to contemporary experience. Jameson's example is Lawrence Kasdan's film Body Heat (1981), which, although it was officially set in the 1980s, feels as if 
it belongs to the 1940s. "Everything in the film", Jameson writes,

conspires to blur its official contemporaneity and make it possible for the viewer to receive the narrative as though it were set in some eternal thirties, beyond historical time. This approach to the present by way of the art language of the simulacrum, or of the pastiche of the historical past, endows present reality and the openness of present history with the spell and distance of some glossy mirage. Yet his mesmerizing new aesthetic mode itself emerged as an elaborated symptom of the waning of our historicity, of our lived possibility of experiencing history in some active way. It cannot therefore be said to produce this strange occultation of the present by its own formal power, but rather merely to demonstrate, through these inner contradictions, the enormity of the situation in which we seem increasingly incapable of fashioning representations of our current cultural experience (Jameson 1991:21).

Sonic hauntology similarly "blurs contemporaneity" with elements from the past, but, whereas postmodernism glosses over the temporal disjunctures, the hauntological artists foreground them. The Caretaker's 2005 six CD box set was entitled Theoretically Pure Anterograde Amnesia, in reference to the neurological disorder which makes sufferers incapable of encoding new experiences in their long-term memory. An abstract soundscape of crackle, fizz and noise which is interrupted only occasionally by the traces of familiar old tunes, Theoretically Pure Anterograde Amnesia simulates the condition of anterograde amnesia, providing what is in effect a new diagnosis of the pathology of postmodernity. Our problem, for The Caretaker as much as Jameson, is not so much that we are seduced by our memories of long ago, but that we cannot produce new memories.

What has all this to do with Afrofuturism? Put bluntly, we might say that postmodernity and hauntology confront "white" culture with the kind of temporal disjunction that has been constitutive of the Afrodiasporic experience since Africans were first abducted by slavers and projected from their own lifeworld into the abstract space-time of Capital. Far from being archaic relics of the past, slaves were thus already in the future. As Žižek put it recently, Haiti's "slave plantations (mostly sugarcane) were not a remainder of premodern societies, but models of efficient capitalist production; the discipline to which slaves were submitted served as an example for the discipline to which wage-laborers were later submitted in capitalist metropolises" (Žižek 2009: 124). Forcibly deprived of their history, the black slaves encountered "postmodernity" three hundred years ago: "the idea of slavery itself as an alien abduction ... means that we've all been living in an alien-nation since the 18th century" (Eshun 1998: A[192]).

Without using either term, Penman's 1995 essay showed that Afrofuturism and hauntology are two sides of the same double-faced phenomenon. The concept of Afrofuturism has always done double work. First, it liberates futurism from the master narratives of white modernity, which positioned Africa as origin, at the furthest remove from the terminus of history projected in Euro-American Science Fictional visions of the future: "The Shape Of Things To Come-a world without war, hurt or hunger (also, tactless enough, without 
black folks)", as Mark Sinker sarcastically summarised these supposed utopias in his crucial 1992 essay "Loving The Alien-Black Science Fiction". Second, Afrofuturism unravels any linear model of the future, disrupting the idea that the future will be a simple supersession of the past. Time in Afrofuturism is plastic, stretchable and prophetic-it is, in other words, a technologised time, in which past and future are subject to ceaseless de- and recompostion. Hip-hop depended on the turntable and the mixer, which converted pre-recorded material from an inert museum into an infinite archive, ripe for recombination; Jungle could only happen when samplers allowed breakbeats to be timestretched, maintaining pitch but increasing tempo and producing the vortical, implosive whorls of sound that prompted Kodwo Eshun to call it "rhythmic psychedelia" (1999: 05[070]).

The fact that Penman's 1995 essay centred on Tricky - the UK artist too "dysfunktional" (Eshun 1998: 03 [059]) to be a rapper, too ill to be illbient-was no accident. For Tricky always belonged to a time that was out of joint, a time-to use the neologism Simon Reynolds innovated to deal with sonic hauntology's temporal displacements-that is dyschronic (Reynolds 2006). Dyschronia is Reynolds' name for the broken-time proper to hauntology, in which it is no longer possible to securely delimit the present from the past, in which the traces of lost futures unpredictably bubble up to unsettle the pastiche-time of postmodernity.

When Tricky began, everything had already ended. "Aftermath", his 1993 first single, is set in a catatonic, post-apocalyptic psycho-geographic undead zone in which personal disaster is indistinguishable from planetary catastrophe. "My first lyric ever on a song was 'your eyes resemble mine, you'll see as no others can", Tricky said when I interviewed him in 2008. "I didn't have any kids then ... so what am I talking about? Who am I talking about? My mother. My mother, I found out when I was making a TV documentary, used to write poetry but in her time she couldn't have done anything with that, there wasn't any opportunity. It's almost like she killed herself to give me the opportunity" (Fisher 2008). The spectral voices come like schizo-radio signal down telepathic lines: the cross-dressing Tricky standing in the empty place where the absent father's law would have been, ventriloquising his dead mother's voice. So writing songs, Tricky says, is not a question of writing at all. It's more like allowing himself to be possessed-which is to say, dispossessed of his conscious self:

It's like meditation, speaking in tongues. My grandmother used to keep me at home because my step-grandfather used to be out working and she used to watch all these black and white horror movies, vampire movies and it was like growing up in a movie and she used to sit me in the middle of the floor, because she lost my mum, her daughter. She'd be playing Billie Holiday, smoking a cigarette and would say things like, you look like your mum, watching me, I was always my mum's ghost (Tricky, in Fisher 2008).

Yet Tricky was a revenant in other ways too. Like everyone else, he originated nothing; instead, he is thrown into a multiply mediated world, a televisual bush of ghosts, a "Cyberjunky spiritworld" (Sinker 1992). "Cyberpunk-white SF, or anyway its radical 
leading edge", Sinker argues in "Loving The Alien", "is arguing that the planet, already turned Black, must embrace rather than resist this: that back-to-nature pastoralism is intrinsically reactionary, that only ways of technological interaction inherited from the jazz and now the rap avant garde can reintegrate humanity with the runaway machine age". Tricky's Afrofuturism, accordingly, is not a question of asserting a purified blackness against a monolithic whiteness, but of maintaining fidelity with his lack of origin. Rather than faking authenticity, Tricky lives liminality; he doesn't resolve the tensions of being mixed race by artificially choosing one side of a racial either/or: instead, his records are a slurred re-dreaming of musics - facilitated by dub and hip-hop methodology - that already blurred white and black: a condensation of psychedelic soul (Marvin Gaye, Sly Stone) and two-tone post-punk (The Specials, Mark Stewart, Japan).

Tricky's "Aftermath", this communion with the dead, is also a labyrinth of (re)citations: it includes quotes from Japan's "Ghosts" ("Just when I thought I was winning...") and a sample of Blade Runner (1982) dialogue (replicant Leon's anti-Oedipal blast: "Let me tell you about my mother"). Yet it's in these "staged reverberations" (Penman 1995) that we can hear the difference between hauntology and postmodernism, its zombie twin. "Aftermath" is no exhausted meta-discourse, no display of self-satisfied self-awareness; the quotations don't suggest a Last Man channel-hop, but a montage, by turns sinister and seductive, in which the cyberpunk near future and the psychoanalytic past echo one another. "Is it merely coincidence that the Sylvian quote and the Blade Runner lift converge in the same song?”, Penman asks. “'Ghosts... Replicants? Electricity has made us all angels. Technology (from psychoanalysis to surveillance) has made us all ghosts. The replicant ('YOUR EYES RESEMBLE MINE...') is a speaking void. The scary thing about 'Aftermath' is that it suggests that nowadays WE ALL ARE. Speaking voids, made up only of scraps and citations... contaminated by other people's memories... adrift..." (Penman 1995).

Modernity was built upon "technologies that made us all ghosts", and postmodernity could be defined as the succumbing of historical time to the spectral time of recording devices. Postmodern time presupposes ubiquitous recording technology, but postmodernity screens out the spectrality, naturalising the uncanniness of the recording apparatuses. Hauntology restores the uncanniness of recording by making the recorded surface audible again. One of the things that the $21^{\text {st }}$ century's hauntological artists-Burial, Ghost Box, The Caretaker-share with Tricky is the foregrounding of the sound of vinyl crackle. There is no attempt to smooth away the textural discrepancy between the crackly sample and the rest of the recording.

If the metaphysics of presence rests on the privileging of speech and the here-and-now, then the metaphysics of crackle is about dyschronia and disembodiment. Crackle unsettles the very distinction between surface and depth, between background and foreground. In sonic hauntology, we hear that time is out of joint. The joins are audible in the crackles, the hiss...

The surface noise of the sample unsettles the illusion of presence in at least two ways: first, temporally, by alerting us to the fact that what we are listening to is a phonographic revenant; and second, ontologically, by introducing the technical frame, the material pre- 
condition of the recording, on the level of content. We are suddenly made aware again of what the first listeners to phonograph recordings were acutely conscious: that we are witnessing a captured slice of the past irrupting into the present. The crackle, meanwhile, reminds us of the technological means by which this capturing of time was made possible. "'Speech has become, as it were, immortal', Scientific American pronounced immediately after Edison's invention [of the phonograph]” (Kittler 1999: 72).

Rock's prehistory has only ever been available to us through a haze of crackle. Owen Hatherley has observed that "there's surely no music more utterly dominated by its recording technology than 1930s blues. Listening to Robert Johnson you have, rather than the expected in $\mathrm{yr}$ [sic] face earthiness and presence, layers upon layers of fizz, crackle, hiss, white noise, as if its [sic] been remixed by Basic Channel rather than recorded in a room in some mythologised deep south" (2006). All that needs to be added to this is the idea that the "mythologized deep south" arises from the "layers of fizz, crackle, hiss, white noise;" there is no presence except mythologically, no myth without a recording surface which both refers to a (lost) presence and blocks us from attaining it. Rockism could be defined as the quest to eliminate surface noise, to "return" to a presence which, needless to say, was never there in the first place; hauntology is a coming to terms with the permanence of our (dis) possession, the inevitability of dyschronia.

Whether or not Robert Johnson really did strike a Faustian bargain, the Gothic dimension of the recording process could not have escaped the imagination of the man who wrote "Phonograph Blues" (1970). What cinema had commented upon and instantiated in films like The Student of Prague (1913) - the uncanny presence of the double-Johnson confronted in the encounter with his recorded voice: the part (object) of himself which would achieve immortality, and returning, buried beneath crackle and hiss, as a phonodoppelgänger. "In the phonographic realm of the dead, spirits are always present" (Kittler 1999: 72). It's no accident that Johnson was recording at around the same time as Al Bowlly (1964), the prewar tearoom crooner whose songs were used by Dennis Potter in Pennies From Heaven (1981) and The Singing Detective (1986), and by Kubrick in The Shining (1980), both of which inspired The Caretaker's music from the haunted ballroom. Both Bowlly and Johnson made records at a time when recording technology had developed sufficiently to achieve a kind of sepia effect but not well enough that the audio simulation had become convincing, life-like. The ellipses in Robert Johnson's life-only a handful of facts are known about him for sure - are another kind of "hiss" that adds to his mystique. It is as if history never happens; either there are too many gaps, which have to be filled with rumours, supposition and fantasy; or there is an excessive, exhaustive record, so complete as to render the narration of history redundant.

We live in a time when the past is present, and the present is saturated with the past. Hauntology emerges as a crucial—cultural and political-alternative both to linear history and to postmodernism's permanent revival. What is mourned most keeningly in hauntological records, it often seems, is the very possibility of loss. With ubiquitous recording and playback, nothing escapes, everything can return. 
This notion of the end or failure of history is one reason that Derrida's neologism of hauntology has been so resonant in the $21^{\text {st }}$ century. Over ten years ago, when Kodwo Eshun published his Afrofuturist manifesto, More Brilliant Than The Sun (1998), Jungle, hip-hop and techno were still consistently generating "future shock". Alvin Toffler coined the term "future shock" in 1965 to refer to "the shattering stress and disorientation that we induce in individuals by subjecting them to too much change in a short time" (Toffler 1981: 2 ). Who were the first victims of future shock if not the African slaves (and the proletariat)? Yet Eshun refused the standard narratives of redemption and damaged wholeness, and instead understood future shock in a positive way. "Change is the process by which the future invades our lives", Toffler had written (1981: 1), and Afrofuturists were those who could identify with the invader, transforming stress into enjoyment. " $[\mathrm{Y}]$ our fear-flight thresholds are screaming, it's like your whole body's turned into this giant series of alarm bells, like your organs want to run away from you. It's like your leg wants to head north and your arm wants to head south, and your feet want to take off somewhere else. It's like your entire body would like to vacate.... Basically, you want to go AWOL from yourself. But you can't, so you stay and enjoy it" (Eshun 1996).

Faced with the mutational acceleration of 1990s Afrofuturist musics, Eshun turned to theoretical components from Deleuze and Guattari and McLuhan in order to combat what he identified as the "futureshock absorbing" tendencies of journalism (1998: 01 [02]). But as the rate of innovation has slackened, as the failure of the future has spread from white postmodernity (even) into the musics of the Black Atlantic, suddenly it is Derrida's work on spectrality which has a new fit with these out-of-joint times.

In addition to being Derrida's book on Marx and Marxism, Specters of Marx can also be read as his engagement with postmodernism. Postmodernism only achieved full-spectrum dominance after 1989, when "apparently victorious" capitalism thought itself in a position to declare the end of history. Derrida's Spectres of Marx is in part about the "end of history" thesis then being propounded by Francis Fukuyama (see Fukuyama 1992). Derrida's title, needless to say, was a play on all of the ghostly imagery in Marx-most notably, of course, the opening line of the Communist Manifesto: "A spectre is haunting Europe-the spectre of Communism". Part of the point was: if communism has always been spectral, what does it mean to say that it is now dead? Derrida's other major reference-plex is Hamlet, especially the line, "The time is out of joint". Here we are back with dyschronia or temporal disjuncture as the principal characteristic of hauntology.

It's no accident that sonic hauntology begins with the Afrofuturist sonic sciences of dub and hip-hop, for time being out of joint is the defining feature of the Black Atlantic experience. As Mark Sinker wrote, the "central fact in Black Science Fiction-self-consciously so named or not-is an acknowledgement that Apocalypse already happened: that (in [Public Enemy's] phrase) 'Armageddon been in effect"' (Sinker 1992). In this disjunctive time, it makes perfect sense for Terminator X to juxtapose samples of helicopters with discussions about the slave trade, as he does on "Can't Truss It" on Public Enemy's Apocalypse... 91 (1991). There is no way in which a trauma on the scale of slavery - "the holocaust still going 
on" as Chuck D had it on "Can't Truss It" - can be incorporated into history, American or otherwise. It must remain a series of gaps, lost names, screen memories, a hauntology. $\mathrm{X}$ marks the spot... a termination of family lineage, a destruction of narrativised time. Compare Octavia Butler's Kindred (1988) — in which a black woman from the bicentennial year of 1976 is abducted back to the time of slavery, and has to protect her slave-owner ancestor-with Toni Morrison's Beloved (1987), in which Sethe kills one of her children in order to save it from the horrors of slavery.

Projected into the looped time of Afrofuturist trauma, Kindred's Dana becomes "like a ghost"- “Disappeared? You mean like smoke?' Fear crept into his expression. 'Like a ghost?" (Butler 1988: 23) - a spectre-from-the-future whose intervention in the past allows that future to happen. The deep, unbearable ache in Kindred arises from the horrible realisation that, for contemporary black America, to wish for the erasure of slavery is to call for the erasure of itself. What to do if the precondition for your being is the abduction, murder and rape of your ancestors?

Morrison's Beloved reminds us that America, with its anxious hankerings after an "innocence" it can never give up on, is haunted by haunting itself. If there are ghosts, then what was supposed to be a New Beginning, a clean break, turns out to be a repetition, the same old story. The ghosts were meant to have been left in the Old World... but here they are. Whereas Kubrick's film of The Shining digs beneath the hauntological structure of the American family and finds an Indian Burial Ground, Beloved pitches us right into the atrocious heart of America's other genocide: slavery and its aftermath. Jonathan Demme's astonishing film of Morrison's novel (1999) was a commercial failure in part due to the fact that the wounds are too raw, the ghosts too Real. When you leave the cinema, there is no escape from these spectres, these apparitions of a Real which will not go away but which cannot be faced. Some viewers complained that Beloved should have been reclassified as Horror... well, so should American history....

The time-slips in Beloved and Kindred often come to mind when you listen to the music of American dub-blues artist Little Axe. Little Axe started releasing records at around the same time as Tricky, and there are certain textual and temperamental between The Wolf that House Built (1994), Slow Fuse (1996) and Tricky's Maxinquaye (1995); and the haunted bayous of Stone Cold Ohio (2006) take their place alongside Burial's phantom-stalked South London and Ghost Box's abandoned television channels in hauntological Now. ${ }^{2}$ Like Tricky's, Little Axe's world is entrancing, vivid, often harrowing; it's easy to get lost in these thickets and fogs, these phantom plantations built on casual cruelty, these makeshift churches that nurtured collective dreams of escape... Also like Tricky's world, the landscape that Little Axe conjure is a religious terrain, by turns infernal, purgatorial, and paradisal.

Shepherds...

Do you hear the lambs are crying?

—"Victims" from Stone Cold Obio (2006) 
Built up out of palimpsests of samples and live playing, Little Axe's records are wracked with collective grief. Spectral harmonicas resemble howling wolves; echoes linger like wounds that will never heal; the voices of the living harmonise with the voices of the dead in songs thick with reproach, recrimination and the hunger for redemption. Yet utopian longings also stir in the fetid swamps and unmarked graveyards; there are moments of unbowed defiance and fugitive joy here too.

\section{I know my name is written in the Kingdom...} _ “Rockin' Shoes" from Stone Cold Obio (2006)

Little Axe is Skip McDonald's project. Through his involvement with the likes of the Sugarhill Gang and Mark Stewart, McDonald has always been associated with future-orientated funk. If Little Axe appears at first sight to be a retreat from full-on future shock-McDonald returning to his first encounter with music, when he learned blues on his father's guitar-we are not dealing here with the familiar, tiresome story of a "mature" disavowal of modernism in the name of a re-treading of Trad form. In fact, Little Axe's anachronistic temporality can be seen as yet another rendering of future shock; except that this time, it is the vast unassimilable trauma, the SF catastrophe, of slavery that is being confronted, but in a more direct way than tended to be the case in Jungle or techno.

Even though Little Axe are liable to be described as "updating the blues for the 21 st century" they could equally be seen as downdating the 21 st century into the early 20 th. Their dyschronia is reminiscent of those moments in Stephen King's It (1986) where old photographs come to (a kind of) life, and there is a hallucinatory suspension of historical sequentiality.

There is no doubt that the blues has a privileged position in pop's metaphysics of presence: the image of the singer-songwriter alone with his guitar provides rockism with its emblem of authenticity and authorship. But Little Axe's return to the supposed beginnings unsettles rockism by showing that there were ghosts at the origin. Hauntology is the proper temporal mode for a history made up of gaps, erased names and sudden abductions. The traces of gospel, spirituals and blues out of which Little Axe's Stone Cold Ohio (2006) is assembled are not the relics of a lost presence, but the fragments of a time permanently out of joint. These musics were vast collective works of mourning and melancholia. Little Axe confront American history as a single "empire of crime", where the War on Terror decried on Stone Cold Ohio's opening track-a post 9/11 re-channeling of Blind Willie Johnson's "If I had My Way" (1957) - is continuous with the terrordome of slavery.

McDonald has described before the anachronizing methodology he uses to transport himself into the past: "I like to surf time. What I like to do is study time-periods-get right in to 'em, so deep it gets real heavy in there" (Real World 2009). McDonald's deep immersion in old music allows him to travel back in time and the ghosts to move forward. Much like Tricky's working methods, it involves a kind of possession. Little Axe's records skilfully mystify questions of authorship and attribution, origination and repetition. It is 
difficult to disentangle sampling from songwriting, impossible to draw firm lines between a cover version and an original song. Songs are texturally dense palimpsests, accreted rather than authored. McDonald's own vocals, by turns doleful, quietly enraged and affirmatory, are often doubled as well as dubbed. They and the modern instrumentation repeatedly sink into grainy sepia and misty trails of reverb, falling into a dyschronic contemporeanity with the crackly samples.

Part of the reason Little Axe are intriguing is that their use of dub makes it possible for us to encounter blues as uncanny and untimely again. Pierre Schaeffer calls sounds that are detached from a source acousmatic (Schaeffer 1966). The dub producer is an acousmatician, a manipulator of sonic phantoms detached from live bodies. "Separated from its cause, the Echoplex creates an ominousness without an object, an all-pervasive feeling of force undefined..." (Eshun 1998: 04[064]). Dub time is unlive, and the producer's necromantic role-his raising of the dead-is doubled by his treating of the living as if dead, the way that he transforms the voice of the living into the "ghosts of ghosts of effects" (Eshun 1998: $04[064])$. For Little Axe, as for the bluesmen and the Jamaican singers and players they channel, hauntology is a political gesture: a sign that the dead will not be silenced.

\section{I'm a prisoner \\ Somehow I will be free \\ _ "Prisoner" from Stone Cold Obio (2006)}

Aт A TIME of political reaction and restoration, when cultural innovation has stalled and even gone backwards, when "power ... operates predictively as much as retrospectively" (Eshun 2003: 289), one function of hauntology is to keep insisting that there are futures beyond postmodernity's terminal time. When the present has given up on the future, we must listen for the relics of the future in the unactivated potentials of the past.

\section{NOTES}

1 This opposition can be deconstructed because, as Mladen Dolar establishes in A Voice And Nothing More (2006), the voice is never other than partly disembodied. The idea that the voice was the guarantor of presence and Logos was only ever a fantasy, as Dolar shows, by uncovering a metaphysical history of voice very different to the one received from deconstruction. Here, far from being the safeguard of presence, the voice was considered to be dangerous, threatening and possibly ruinous. Dolar's argument is that Law-Logos has always sought to differentiate itself from a voice conceived of as feminine and chaotic, but Logos cannot extirpate the voice, and indeed depends upon it: what is the fundamental expression of the Law if not the voice of the Father?

2 See Burial's debut—and Hyperdub's first release-South London Boroughs (2005). 


\section{REFERENCES}

Butler, Octavia. 1988. Kindred. London: The Women's Press.

Buse, Peter and Stott, Andrew. 1999. "Introduction: a Future for Haunting”. In Ghosts:

Deconstruction, Psychoanalysis, History, ed. Peter Buse and Andrew Stott, 1-20 . London:

Palgrave.

Derrida, Jacques. 1976. Of Grammatology. Baltimore and London: Johns Hopkins University Press.

- - - 2006. Specters Of Marx. New York and Abingdon: Routledge.

Dolar, Mladen. 2006. A Voice and Nothing More. Cambridge, MA and London: MIT Press.

Eshun, Kodwo. 1996. "Abducted By Audio (Live)". Cybernetics Culture Research Unit. < http://www.ccru.net/swarm3/3 abducted.htm> (accessed 8 November 2009).

- - 1 1998. More Brilliant Than The Sun: Adventures In Sonic Fiction. London: Quartet.

- - - 2003. "Further Considerations On Afrofuturism". CR: The New Centennial Review 3 (2): 287-302.

Fisher, Mark. 2008. "Interview with Tricky". The Wire. <http://www.thewire.co.uk/ articles/1222/?pageno=3> (accessed 11 August 2009).

Fukuyama, Francis. 1992. The End Of History And The Last Man. Harmondsworth: Penguin.

Hatherley, Owen. 2006. "Well, that was actually more in the ragtime idiom". Sit Down Man, You're A Bloody Tragedy. 9 October: <http://nastybrutalistandshort.blogspot.com/2006/10/wellthat-was-actually-more-in-ragtime.html $>$ (accessed 11 August 2009).

Jameson, Fredric. 1991. Postmodernism, Or The Cultural Logic OfLate Capitalism. London: Verso.

King, Stephen. It. 1987. Sevenoaks: Hodder and Stoughton.

Kittler, Friedrich. 1999. Gramophone, Film, Typewriter. Stanford: Stanford University Press.

Marcus, Greil. 1977. Mystery Train: Images Of America In Rock 'N'Roll Music. London: Omnibus Press.

Morrison, Toni. 1987. Beloved. London: Chatto and Windus.

Penman, Ian. 1995. "[the Phantoms of] TRICKNOLOGY [versus a Politics of Authenticity]". The Wire 133 (March). <http://www.rocksbackpages.com/article.html?ArticleID=4025> (accessed 11 August 2009).

Real World. Little Axe. <http://www.realworldrecords.com/artists/little-axe/> (accessed 12 August 2009).

Reynolds, Simon. 1995. "Interview with Tricky". Melody Maker, 24 June: <http://www. rocksbackpages.com/article.html?ArticleID=988> (accessed 11 August 2009).

- - . 2006. "Haunted Audio". The Wire 273 (November): 26-33.

Schaeffer, Pierre. 1966. Traité des objets musicaux. Paris: Le Seuil.

Sinker, Mark. 1992. "Loving The Alien-Black Science Fiction”. The Wire 96 (February). <http://www.thewire.co.uk/articles/218/> (accessed 10 August 2009).

Toffler, Alvin. 1981. Future Shock. Toronto, New York and London: Bantam.

Žižek, Slavoj. 2009. First As Tragedy, Then As Farce. London and New York: Verso. 


\section{DISCOGRAPHY}

Bowlly, Al. 1964. Al Bowlly Sings Again. Ace of Clubs (LP): ACL 1162. <http://www.discogs.com/Al-Bowlly-Al-Bowlly-Sings-Again/release/678663>.

Burial. 2005. South London Boroughs. Hyperdub (12-inch): HDB001. <http://www.discogs.com/Burial-South-London-Boroughs/master/102146>.

-——. 2006. Burial. Hyperdub (CD): HDBCD001. <http://www.discogs.com/Burial-Burial/master/11767>.

Caretaker, The. 2005. Theoretically Pure Anterograde Amnesia. V/Vm Test Records (MP3): VVMTCD25. < http://www.discogs.com/ Caretaker-Theoretically-Pure-Anterograde-Amnesia/master/18444>.

Ghost Box (label). 2004-. <http://www.discogs.com/label/Ghost+Box>.

Little Axe. 1994. The Wolf That House Built. Wired Recordings (CD): WIRED 27. $<$ http://www.discogs.com/Little-Axe-The-Wolf-That-House-Built/master/142594>.

- - . 1996. Slow Fuse. Wired Recordings (CD): WIRED 0233. <http://www.discogs.com/Little-Axe-Slow-Fuse/master/15876>.

—— - 2006. Stone Cold Ohio. Real World Records (CD): USCDRW 140. <http://www.discogs.com/Little-Axe-Stone-Cold-Ohio/master/15880>.

Johnson, Blind Willie. 1957. His Story. Folkways Records (LP): FG 3585. <http://www.discogs.com/Blind-Willie-Johnson-His-Story/release/748067>.

Johnson, Robert. 1970. King of the Delta Blues Volume II. Columbia (LP): C 30034. <http:// www.discogs.com/Robert-Johnson-King-Of-The-Delta-Blues-Vol-II/master/150637>.

Public Enemy. 1991. Apocalypse 91... The Enemy Strikes Back. Def Jam Recordings (CD): 523 479-2. $<$ http://www.discogs.com/Public-Enemy-Apocalypse-91-The-Enemy-Strikes-Black/ master/30225>.

Tricky. 1993. Aftermath. Fourth \& Broadway (CD): 12 BRW 288. <http://www.discogs.com/Tricky-Aftermath/master/50201>.

- - 1995. Maxinquaye. Fourth \& Broadway (CD): BRCD 610. <http://www.discogs.com/Tricky-Maxinquaye/master/50297>.

\section{FILMOGRAPHY}

Kasdan, Lawrence. 1981. Body Heat. USA: The Ladd Company.

< http://www.imdb.com/title/tt0082089/>.

Kubrick, Stanley. 1980. The Shining. UK-USA: Warner Bros.

<http://www.imdb.com/title/tt0081505/>.

Potter, Dennis. 1986. The Singing Detective. UK-Australia: BBC-ABC

<http://www.imdb.com/title/tt0090521/>.

Ross, Herbert. 1981. Pennies from Heaven. USA: MGM.

$<$ http://www.imdb.com/title/tt0082894/>.

Rye, Stellan and Paul Wegener. 1913. Der Student von Prag (The Student of Prague). Germany:

Deutsche Bioscop GmbH. <http://www.imdb.com/title/tt0003419/>.

Scott, Ridley. 1982. Blade Runner. USA-Hong Kong-UK: Warner Bros. < http://www.imdb.com/title/tt0083658/>. 